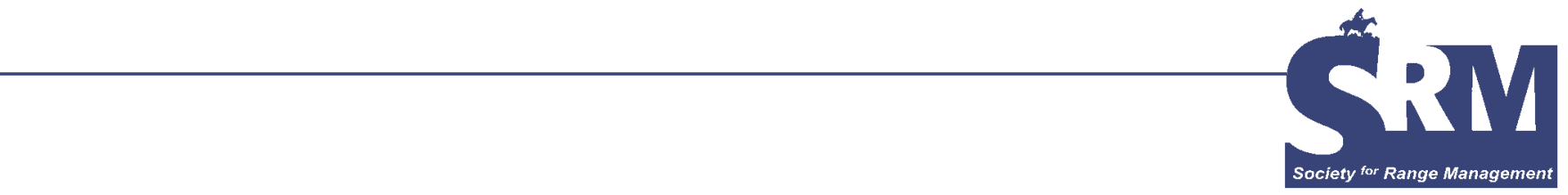

\title{
Taking the Reins
}

\section{Nevada and Idaho have taken a proactive stance on selling ranch stewardship to the public.}

\section{By Kindra Gordon}

$\mathrm{P}$

ut a cowboy on a TV commercial or in a magazine ad and odds are pretty good that you can sell about anything. Companies like Marlboro, Budweiser, and Dodge have been using that tactic for decades.

Now 2 entities in Idaho and Nevada are embracing the cowboy image as well to help garner urban support for the important role their states' ranching industry has in land stewardship.

Gretchen Hyde with the Idaho Rangeland Resource Commission (IRRC) explains that the goal is to raise awareness with the nonranching public about land management and help them understand that grazing is beneficial to the land.

She adds, "The need to educate the nonranching public about rangelands is becoming more important every day."

Indeed. With nearly $90 \%$ of both Idaho and Nevada federally owned and managed, the public has a large role in determining how those lands are used, which can make it a difficult environment for ranchers-especially with regard to legislative issues. And as fewer Americans have farm roots - or even know someone who lives on a farm - there is an increasing disconnect between rural and urban communities and issues.

To bridge that information gap, the state legislature in each of these neighboring states established their own rangeland resource commission a few years back.

\section{Nevada's Efforts}

The Nevada Legislature-spurred by state senator Dean Rhoads, who is a rancher himself-created the Nevada Rangeland Resources Commission (NRRC) in 1999. The NRRC's stated mission is to inform the public that Nevada's rangelands are a vital economic resource, protected and preserved for all citizens by a stable, sustainable livestock industry.

To carry out its information and education campaign, the NRRC collects 10 cents per animal unit month from public land ranchers and uses the money for the promotion, outreach, education, and research necessary to inform the public about the benefits of livestock grazing on public lands.

Some examples of NRRC's efforts include the following:

- Using print media and radio spots featuring scenic ranch images and people like popular rodeo announcer Bob Tallman.

- Participating in the Las Vegas Farm Festival, where nearly 7,400 kindergarten through fourth grade children were taught how ranching can benefit both livestock and wildlife.

- Hosting performances of western music and range poetry with "Texas" Tom Weatherby and Dennis Golden-and having the performers emphasize the important role of ranchers and rangelands.

- Placing billboards around the state that send the NRRC's message of healthy and productive range management to passing motorists. The billboards were put up this fall ( 2 along US 93 and 3 along I-80 near Winnemucca, Elko, and Reno) and will stay up for 6 months.

\section{Idaho's Initiative}

The NRRC is patterned after a similar Rangeland Resources Commission in Idaho that was established by its state legislature in 1994 to promote ranching and rangelands to city slickers.

Today, more than a decade since it was founded, and operating with a budget of $\$ 200,000$, the IRRC is a resource for the urban community it set out to educate. Projects include 
maintaining a Web site with information on frequently asked questions, links to grazing information, and the opportunity to "ask a range manager" questions. The site includes "stuff for students," as well as teacher resources. Additionally, the IRRC in conjunction with the University of Idaho offers a summer seminar for teachers to help them learn about rangeland ecology and bring it into their classrooms.

Hyde reports that the weeklong teacher workshops have been especially well received. "The focus is on rangeland ecology rather than grazing, but by the end of the week the teachers understand that management and grazing is necessary to keep lands healthy and productive," she says.

Also for the classroom, the IRRC has created an Idaho history curriculum for fourth grade teachers, and a science protocol is available for teachers who want to incorporate it into their curriculum.

Most recently, the IRRC has implemented the Care/ Share public relations campaign designed to help ranchers and outdoor enthusiasts understand multiple uses on rangelands. The message behind the campaign is a noble one for the West-it states there is room for everyone, if we care for the land and treat one another with respect.

To help promote awareness for the Care/Share concept the IRRC created a unique radio campaign that aired this past summer aimed to educate the general public about livestock and the land.

Hyde says the radio spots took a humorous, tongue-incheek approach by using talking animals like cows, dogs, and sheep, but still the message about respecting each other on the land was clear. The 3 radio spots targeted hikers and bikers who might be out on public lands, and the topics addressed emphasized why it's important to close a gate if you open one, how to respond if you encounter a guard dog with a sheep herd, and why it's important to respect private property that may be intermingled with public lands.

Along with the radio messages, Hyde says that the IRRC offers complimentary signage for ranchers to post on the land. "These signs offer information about the management that's going on or remind recreationists to close gates. They are designed to create awareness and continue educating those who may be using the land," Hyde says.

All total, Hyde believes the campaign is making inroads. She reports that in past years, the IRRC has frequently gotten a lot of calls questioning livestock use on public lands, but she says, "That didn't happen this past summer. I think it's because more people are becoming aware of what ranchers are doing out on the land."

Ranchers appear to be supportive of the program as well. Hyde says at this point they have a less than 3\% request for refund on the assessments that are received from public and private lands.

Looking to the future, Hyde says she is hopeful other Western states will implement similar efforts to educate the nonranching public. She says, "To have more of the Western states doing this would make a huge difference because it's a big issue."

For more information about these two programs visit www. nevadarangelands.org and www.idrange.org.

Editor's Note: This article originally appeared in the February 2006 issue of Western Cowman and is reprinted here with permission from the author.

Author is a freelance writer based near Sturgis, South Dakota, and has been a member of the Society for Range Management since 1992,office@gordonresources.com. 